in the Museum will be available for meetings of Sections in which the lime-light is indispensable. The dates and hours at which this room will be available must be settled by the Recorders of Sections during the meeting.

The arrangements for excursions in the neighbourhood are now complete. The list is not as long as has been the case in some recent meetings, as the localities of general interest which are accessible from Oxford are few in number. On the Saturday afternoon parties will be taken to Dorchester and Wallingford, to Abingdon, to Blenheim Palace and Woodstock, and to the Roman remains at Silchester, and Prof. Green will take a geological party through Fawler to the classical grounds of Stonesfield. On the Thursday, whole day excursions are arranged for Windsor and Eton, Warwick and Stratfordon-Avon, Compton Wynyates, Broughton and Wroxton, Reading, and the Great IVestern Railway Works at Swindon.

The total number of those who have up to the present signified their intention of attending the meeting amounts to a little over 1500 . As the Sheldonian Theatre, on the most liberal estimate, will not accommodate more than 1800 persons, and as it is very probable that the number of applicants for places will be greater than this, members and associates are recommended to apply for places in the Theatre for the President's address and evening lectures as early as possible. The allotment of seats will begin on Monday, August 6.

$U_{p}$ to the time of writing, but little information has been received respecting the work of the various Sections. In Section D (Biology) the President, Prof. J. Bayley Balfour, will deal in his address with the aspects of forestry in Great Britain, and among other papers which will be read to the Section, Prof. Ray Lankester will make a communication on chlorophyll in the animal kingdom, Prof. A. A. IV. Hubrecht will read a paper on the Didermic blastocyst, and Mr. J. T. Cunningham on the specific and generic characters of the Pleuronectidae.

In Section E the President, Captain W. J. L. Wharton, R.N., will deal in his address with our present knowledge of the physical conditions of the sea. And among other papers which will be read at the meeting are the following :-Colonel Godwin Austen, on Bhotan; Mr. Osbert H. Howurth, on the Sierra Madre of Mexico ; Miss Baildon, on a visit to. New Guinea; Mr. D. G. Hogarth, on a recent journey in Asia Minor; Mr. W. H. Cozens Hardy, on Montenegro and Albania; Dr. H. Schlichter, on the natural wealth of British East Africa; Mr. G. G. Chisholm, on the orthography of Place-names; NIr. J. Theodore Bent, on Hadramut; Mr. A. Montefiore, on the equipment of the Jackson-Harmsivorth Arctic Expedition; Mr. H. N. Dickson, on the physical condition of the North Sea; M. A. Delbecque, on the lakes of France, and Dr. H. R. Mill, on the geography of the English lakes. The proceedings of the other sections will be announced as soon as they are communicated.

\section{THE BIOLOGICAL INSTITUTION IN BERGEN, NORWAY.}

I AST autumn a biological institution was opened in Lergen. It forms part of the museum, the library and collection of which the students are at liberty to use.

The building is of wood, two storeys high. On the ground floor there is one large hall surrounded on three sides by aquaria, which are open to the public on payment of a small entrance fee. Then there is the pumproom, and other rooms, one of which is used for experiments in hatching, and in the others the collected matter is examined and studied, and the dredges and other instruments are kept. There are two hatching apparatus, each containing eight hatching-boxes. A hatching apparatus for fresh water is much required, so that the biological questions in connection with the salmon. fishing may be worked out.

Fig. I is the plan of the ground floor.

The first floor is set apart for scientific work, and consists of two large rooms, the smaller of which is used for chemical work, and is furnished with all necessary apparatus.

The larger room has four windows on each side; those on the east are separated by wooden partitions, curtained off from the rest of the room, thus forming four small work-rooms, each of which is furnished with a microscope and writing-table and other conveniences for the work of one person. In front of the windows on the west side, there are tables (L, Mr, N, O,

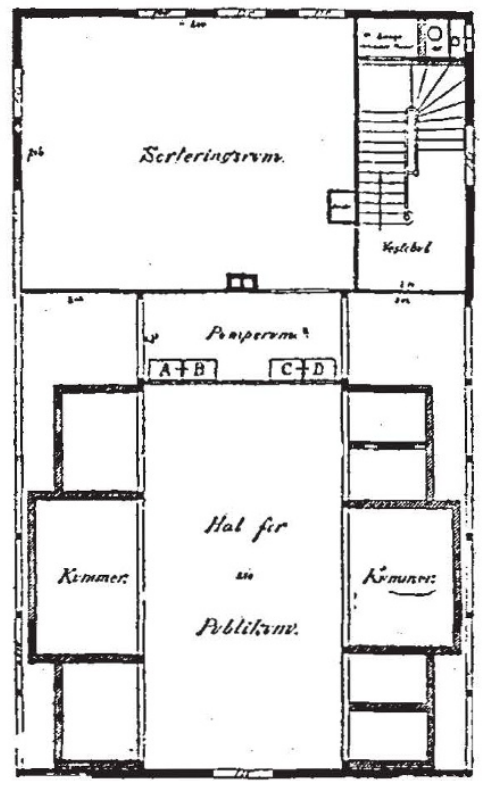

Fig. r.-Ground floor Fig. 2).

Altogether ten work-tables are provided in the institute.

In the middle of the larger room there is a long low $\operatorname{sink}(E, F, G, H, F i g . ~ 2)$, which has a small channel in the middle connected with a waste-pipe. On each side of

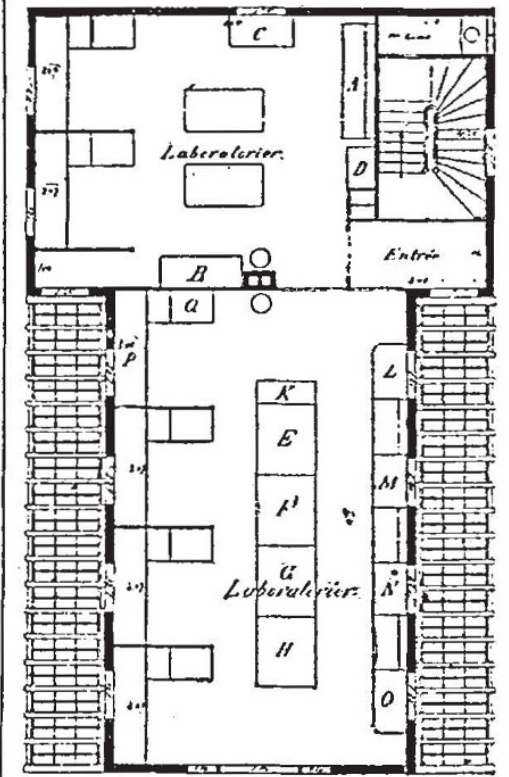

Fig. 2.-First floor. this sink, but raised slightly above it, there is a shelf running the whole length of it, and wide enough to hold the small experimental aquaria, which consist of glass bowls. Above the shelves are pipes from the sea: water reservoir,with numerous taps, thus supplying flowing water when necessary.

The sea-water supply is conveyed to the pump-room by means of a long pipe from the middle of the Paddefjords, at a depth of ten metres; from here it is pumped up to the reservoir, which is on the top storey, whence it supplies the laboratories.

The fauna is very rich; the flora has not yet been much studied.

The biological institution is for foreign as well as Norwegian students. The monthly cost for the use of NO. I 290 , VOL. 50] 
one of the work-tables is twenty-five kronen. This includes the necessary reagents, the free use of all the apparatus and the museum, also the use of the boat, with the men, for private explorations, and liberty to take part in the weekly steamer excursions to the distant parts of the fjords.

The institution is open every day all the year round; the fjords are never quite frozen, and at the coldest time the temperature is never more than a few degrees from zero.

The institution is under the supervision of Herren $\mathrm{Dr}$. A. Appellöf, G. A. Hansen, and T. Brunchorst. It is almost entirely supported by voluntary contributions. A certain sum, however, is granted by the State, which unfortunately is not sufficient to permit the institution to have a resident zoologist ; but as the Norwegian Government is always so liberal in matters of a scientific nature, it is hoped that the required amount will soon be granted.

\section{PROFESSOR DR. FISCHER.}

$\mathrm{BY}$ the death of Prof. Dr. Fischer, which took place on May 17 last, the Königliche Preussische Geodätische Institut and the Central-bureau der Internationalen Erdmessung lose a very ardent and devoted chief who has done much, not only to keep up the high standard of these institutions, but to bring them, if possible, to a higher grade of perfection.

Born in the year 1836 , on December Io, at DeutschLeippe, near Grottkau, in Schlesien, Amand Fischer began his first studies at the Mathias-Gymnasium in Breslau, occupying his attention, among other things, with mathematics and science (Astr. N $N^{\prime} a c h$. Bd. 135, No 3235); he graduated in 1866, the subject of his dissertation being the Comet III. of 1860 . In the following year he entered in the Central-bureau der Mitteleuropäischen Gradmessung, and two years later in the Königliche Preussische Geodätische Institut, in which he commenced his great activity, which he continued up to the end. From July 1877 he conducted the sections relating to Geodesy.

Among the numerous valuable works brought before the public will be remembered the "Rheinische Dreiecksnetz," in which were a great number of Fischer's measurements, made at the majority of the stations em. ployed. He found occasion also to busy himself with lateral refraction, and he made an interesting contribution on "Lothabweichungen in der Ungebung von Berlin" (I889), which was valuable in the discussion regarding the relation between Geodesy and Geology.

At a somewhat earlier date, in an article that appeared in the Astr. Nach. (Bd. 88), entitled "Die Gestalt der Erde und die Pendelmessungen," he brought forward the interesting deduction that the variation, which $\mathrm{Ph}$. Fischer had calculated from the measures of gravity, could be traced back to geological causes, a deduction which agrees very neariy with our present ideas.

The publication of the "Berliner Basisnetzes" (IS9I) absorbed a great amount of his activity, as he paid special attention to this piece of work. In the measurements made in the Strehlen, Berlin, and Bonı base-lines operations, he took, finally in the capacity of director, a prominent part. We have to thank him, also, for some important thermoelectrical researches on the expansion of the rods used for base-line determinations. (Astr. Nach. Bd. I03.) He determined, also, the difference of longitude between Wangeroog and Schillig by means of optical signals, during the time of the operations on the trigonometrical survey of the North Sea islands and the mainland, with the computation of which he busied himself.

We are indebted to him for a great number of astronomicai observations made at several stations for the trigonometrical work in which he was employed.
In order to get some idea of his dexterity and care, and more especially of his love for work and his selfsacrifice, one must not only look at the literary side of Fischer's activity, but at that in which his capacity as an observer was a very prominent feature.

Besides a host of numerous friends who mourn his loss, he leaves behind a widow and three children.

\section{NOTES.}

THE subjects for 1895 for the results of original research, upon which the Royal Society of New South Vales offer their medal and $£ 25$, are as follows:-(I) On the Silver Ore Deposits of New South Wales. (2) On the Physiological Action of the Poison of any Aust ralian Snake, Spider, or Tick. (3) On the Chemistry of the Australian Gums and Resins. The com. munications are to be sent in not later than May 1,1895 . The subjects for 1895 are also announced as follows:-(r) On the Origin of Multiple Hydatids in Man. (2) On the Occurrence of Precious Stones in New South Wales, with a description of the deposits in which they are found. (3) On the Effect of the Australian Climate on the Physical Development of the Australian-born Population. The Society emphasise the condition that the atvard will not be made for a mere compilation, however meritorious it may be.

Tre Council of the Royal Sosiety of New South Wales have awarded the prize given by the Hon. Ralph Abercrombie for the best essay on "Southerly Bursters" on the east coast of Australia, to Mr. Heary A. Hunt, second meteorological assistant in the observatory at Sydney. The essay contains the results obtained from a study of all the bursters that visited the east coast from 1863 to 1893 , and is illustrated by weather charts, cloud photographs, and diagrams showing the monthly and hourly distribution of these wind storms, as well as diagrams showing instrum ental conditions in typical cases.

Manuscripts competing for the De Candolle Prize for 1895 , offered by the Geneva Physical and Natural History Society, for the best unpublished monograph of a genus or family of plants, must be sent in by January 15,1895 . They may be written in Latin, French, German, English, or Italian. The value of the pri ze is 500 francs.

LIVERPOOL is fortunate in having citizens who testify their interest in the scientific welfare of the city by munificent generosity. We have previously noted the endowments, by the Earl of Derby and Mr. George Holt, of chairs in anatomy and pathology at the University College, Liverpool. IVe now learn, from the British Medical Fournal, that the Kev. S. A. Thompson Yates has presented the College with the sum of $£ 15,000$ in order to build physiological and pathological laboratories.

THE Danish Government has undertaken, during the years 1895 and 1896, a deep-sea exploration in the Greenland and Icelandic waters. The expedition will be accompanied by a butanist.

ONE of the last acts of the late President Carnot, a few hours before his assassination, was to confer on the well-known botanist Dr. Saint-Lager the dignity of Officer of Public Instruction.

Dr. V. SCHIFFner has sent to the Botanical Institute of the German University of Prag a very large collection of dried plants and spirit-material from IVestern Java. He is intending also to visit Eastern Java and Sumatra.

THE antiquities, ranging from prehistoric down to Roman times, lately discovered by Prof. Flinders Petrie in the temple of Ioptos in Upper Egypt, will be exhibited to the public in 